\section{Resistance to Resilience: Journey of a Young Girl from Home to ART Center}

\author{
Anu Malik* and Shikha Dixit \\ Department of Humanities and Social Sciences, Indian Institute of Tech- \\ nology, Kanpur, India
}

\begin{abstract}
This is the story of Akanksha, a young college going girl, who was tricked into prostitution and who eventually got infected with Human Immunodeficiency Virus (HIV). She was born in a less privileged household in the suburbs of Kanpur, a city in the northern state of India. Her story brings into light the ways in which Anti-Retroviral Therapy (ART) centers are not only providing preventive medications to those living with HIV, but they are a source of information to the unaware. They play a significant role in slackening the spread of HIV. These centers are opening the doors of communication among the People Living with HIVIAIDS (PLWHA). The protagonist in the story below explicitly narrates her journey from home to prostitution in search of a good life. She further discusses her expectations from ART center from a PLWHA perspective. The story below is not only a demonstration of how ART centers influence the lives of PLWHAs but it is also a testament of what PLWHAs require apart from the preventive medication and awareness programs.
\end{abstract}

Keywords: ART center; HIV; People living with HIV; Prostitution

\section{Introduction}

"I am the eldest in my family and the sole earning member. My younger siblings are dependent upon me now. Down my memory lane I remember my father existing only as a drunkard; he would earn only to drink. My mother worked as a house help and supported us. She always motivated us to study well and rise above the shackles of poverty. We were poverty-stricken but still she managed our education in the government funded schools and then colleges. I joined college

*Corresponding author: Anu Malik, Department of Department of Humanities and Social Sciences, Indian Institute of Technology, Kanpur - 208016, UP, India Tel: + 91 8874440534; E-mail: malika@iitk.ac.in

Citation: Malik A, Dixit S (2017) Resistance to Resilience: Journey of a Young Girl from Home to ART Center. J AIDS Clin Res Sex Transm Dis 4: 016.

Received: September 25, 2017; Accepted: December 15, 2017; Published: December 29, 2017 and like all other college going girls I had dreams of a good-life. My parents were not in a position to fulfil them. I would try to get what I needed on my own. I have always liked watching movies, eating out with friends, wearing shimmery clothes and glittery shoes and using technologically advanced smart phones. My friends could easily afford all these; they never had to put any extra efforts for these things. My friends brought me all the gossipy news, since our household had no television. My friends had been my access to the world of entertainment. They would discuss the TV shows and in such situations I always felt left-out. I liked them, I wanted to be like them and I wanted to live the life they lived. My friends had fathers who slogged to make ends meet and mothers who earned a buck here and there by working as domestic-helps. Consequently my friends could afford second-hand TVs and refrigerators but I couldn't. I felt angry at my father, who drank the cheaply available local alcohol, since that was all he could afford.

In such a phase of personal, social and emotional conflict when every adolescent needs his/her parents' guidance, my mother began ailing and because we could not afford expensive treatment, gradually she became bed ridden. She lay on her bed staring at the wall, blinded by the dark patches that decorated the wall, like someone absorbed in a piece of abstract art. My father was never concerned about us or our mother. He would only manage to somehow get something to cook and of course his own drinks. During this adverse point in my life a neighbour whom I have always addressed as uncle helped us many times. He would lend us money, bring chocolates, sweets and sometimes he would even give us new clothes on festivals. One day he called me to his home and introduced me to a man I had never seen before. He took me aside and told me that if I make him 'happy' he would get me all I have ever wanted. I hesitated, but my uncle pushed me in the room saying "this will change your life forever." I did not get any time to think and before I could realize what had happened and make some sense of the situation, he handed me a bundle of hundred rupee notes. I did not count them but I had never seen these many hundred rupee notes in my life. I took them and left. On the way back home I bought the pair of earrings I had always wanted, ate chaat $^{l}$, bought vegetables, daal ${ }^{2}$ and rice. My family had a good meal that day. We never had lentils and vegetables together. I bought many things and still I had money left with me.

I had always wanted to treat my friends, but could never do so. That day I had enough money so I took my friends to the college cafeteria and paid the bill. I went for shopping, bought a new dress and a pair of shoes. I felt empowered and realised that it is not that difficult to make money. This was my first step towards a gripping life of instant gratification that would eventually lead to discontentment and disgruntlement. Form this point onwards it was a never ending story of fascinations, one after the other. I bought a mobile phone, a television set, a pair of heels, many beautiful dresses to wear in the college, whole range of products for make-up, colourful bags . . . but the list of wants kept on increasing. My mother was still bed-ridden; neither recovering nor sinking. But, my father had changed now, he had even stopped bothering about the food. He knew that I would get something and cook. His lone concern was drinking alcohol. He

1. Chaat -A savory snacks typically served at road-side tracks from stalls in India

2 Daal - South Asian term for dried and split pulses 
would even pester me for money but never bothered to know from where it was coming? I was not concerned about these issues. By then violence had become apart of my life. It happens in our 'work'. All my needs as well as greeds were being fulfilled. I didn't mind paying the school fees for my two younger siblings, who were school-going. I never indulged in serious thinking about my situation. I would go to college, not much interested in studies, but more interested in displaying my belongings. I would always ignore my friends who asked "from where do you get all this". My life was in full swing and then suddenly I got the jerk.

It was during my menstrual cycle, that I felt high fever and a terrible headache. That day I had to suspend my activities, I neither went to college nor for 'work'. I took some medicines that brought down the symptoms but could not control them. The symptoms appeared and reappeared for almost a month. I discussed the matter with a friend of mine, my confidante. She took me to the doctor and got me tested for HIV. Before getting me tested she did not inform anything but later she explained to me everything about the illness. My life shattered when I got to know that I was infected with HIV. It was a dismaying discussion because I was diagnosed with HIV. If at the young age of 22 years life had sentenced me to a certain death, what was the point in waiting for that death? It would come nonetheless, in a year, two years, ten years or may be more. I thought of dying and contemplated suicide for almost a week and then I executed my plan. I swallowed phenol, but the volume I poured in was not enough. I had decided not to live and in the moment of finality I tried the ceiling fan and the rope too, only I tried it with my mother's saree and not an actual rope. It failed miserably too the already tattered saree gave up on my weight the moment I kicked the stool on which I stood. After two failed suicide attempts it was fairly clear that I had to live.

I began my visits to the ART center. The staff at ART center was a mixed lot of positives as well as negatives serostatus. All the HIV positives there were a mixed lot too young, old, men and women. There is a NGO working for the PLWHA and the advisors from the NGO were kind to me. They explained to me that I still have a life ahead, if I took good care of myself and kept taking the medicines regularly. During my early visits to the ART center people told me that I will be discriminated for my serostatus in the society. On my first visit to the ART center I got the idea that disclosing my illness would result in discrimination and isolation. Discrimination was fine! People anyways discriminate against the female. There are all sorts of discriminations! I am immune to all the hurling, but now I lacked the much needed immunity against the virus. ART center not only made me aware about the prevalent stigma and discrimination in the society but there I also got to know about the modes of HIV transmission. At that point I knew how I got it and I regretted why I had not known it earlier. I should have been aware about HIV. After all I was literate. However, it seems that literacy and awareness are not much linked. These things are not taken seriously in the school curriculum. The staff at ART center provides us with the information about medication, its side effects and the ways in which these medicines suppress the virus. They counsel us on a personal level. The ART center works as a unit together to fight against HIV. There are certain issues sometimes. There is shortage of medicines and this increases the number of visits to the ART center and further adding to the cost of transportation and loss of work. It is a platform where all the HIV positive people meet, discuss their problems, feelings and issues which they face. Group discussions and personal counselling sessions are also conducted here from time to time.
I would like to point out here that people living with HIV should be provided with employment opportunities in accordance with their abilities. I want to leave prostitution. There is so much violence and morally it is a burden on me. I ask my clients to use condoms. Some do and some ignore my request. I cannot tell them that I am HIV positive. This would result in no income and I have a hungry family which has a parasitic existence on me; just as the hateful viruses in my body. Based on my conversation with other PLWHA and my own experience I can say that now there is only one hope for us and that is a cure for HIV. I wish for it to come soon".

\section{Critical Insights}

The above story is extracted from the field work conducted for 10 months from 2014-15. The National AIDS Control Organization in their annual report (released on every World AIDS Day, December 1) estimated 2.17 million PLWHA in India [1]. The large numbers of PLWHA as well as the vulnerable population, portray a need to identify underlying potential factors which can prompt the spread of virus. The above story clearly elucidates certain challenges which need to be taken care of in collaboration with the ART center.

- Counselling post the diagnosis of HIV, should strategically focus on curbing suicidal thoughts

- HIV can be a cause as well as a consequence of poverty. So there is a need to address the employment requirements of people living with HIV. World Health Organization identified HIV as a 'manageable chronic illness'; thus a person can manage employment and health issues simultaneously [2]

- Providing timely medications so that the people suffer minimum financial loss (daily wages) and incur minimum transportation cost. Shortage of ART medication has been reported in the newspaper and research articles [3-5]

- Planning strategic measures to educate people about the use of condom during transactional sex, as well as with regular sexual partners

- Awareness programs about the HIV transmission through social media

- In order to socially empower the PLWHA it is equally necessary to economically empower them. To economically empower PLWHA, skill development and self-employment programs should be formulated

ART centers across India are working towards better treatment facilities for PLWHA but they should also consider the economic and social aspects to further facilitate people living with HIV and eradicate it. There are clear linkages between poverty and HIV and this story clearly portrays how poverty can make people vulnerable and push them towards transactional sex [6,7]. HIV is an illness which is accompanied by the issues of suicidal thoughts, experiences of violence, issues of moral burden and guilt [8-11]. However, an optimistic attitude has the power to change the course of life. The above story is an example that how contemplating suicide is a subsequent reaction to HIV and with proper guidance and counselling in the ART center. Akanksha is now managing her illness by adhering to the treatment. Embracing a ray of hope to be cured someday. 


\section{References}

1. National AIDS Control Organization (2015) NACO HIV Estimation Technical Annual Report 2015-2016. NACO, New Delhi, India.

2. World Health Organization (2003) Adherence to Long-Term Therapies: Evidence for action. WHO, Geneva, Switzerland.

3. Malik A, Dixit S (2017) Barriers to Antiretroviral Therapy Adherence. Economic \& Political Weekly (Vol 52). Mumbai, India.

4. Hamid Z (2015 Drug shortage troubles HIV/AIDS patients. The Hindu, Chennai, India.

5. Smith L (2014) India: 150,000 HIV/AIDS Patients Face Life-Saving Drugs Shortage Over 'Bureaucratic Hurdles'. International Business Times, New York City, USA.

6. Rodrigo C, Rajapakse S (2010) HIV, poverty and women. Int Health 2 9-16.

7. Dandona R, Dandona L, Gutierrez JP, Kumar AG, McPherson S, et al. (2005) High risk of HIV in non-brothel based female sex workers in India. BMC Public Health 5: 87 .
8. Mollan KR, Smurzynski M, Eron JJ, Daar ES, Campbell TB, et al. (2014) Association between efavirenz as initial therapy for HIV-1 infection and increased risk for suicidal ideation or attempted or completed suicide: an analysis of trial data. Ann Intern Med 161: 1-10.

9. Verma R, Pulerwitz J, Mahendra VS, Khandekar S, Singh AK, et al. (2008) Promoting Gender Equity as a Strategy to Reduce HIV Risk and Gender-based Violence Among Young Men in India. Horizons Final Report, Population Council, USAID, Washington, DC, USA.

10. Thomas F (2008) Indigenous narratives of HIV/AIDS: morality and blame in a time of change. Med Anthropol 27: 227-256.

11. Hamann C, Pizzinato A, Weber JLA, Rocha KB (2017) Narratives about risk and guilt among patients of a specialized HIV infection service: implications for care in sexual health. Saúde e Sociedade 26: 651-663. 